\title{
Marx, Engels og dialektikken
}

\author{
Terrel Carver*
}

Hensigten med denne artikel er atter at undersøge det intellektuelle forhold mellem Karl Marx og Frederich Engels, specielt deres samarbejde om Engels' Anti-Dühring, der er »den bedst kendte lærebog i marxistiske kredse « og grundlaget for Engels' endnu mere indflydelsesrige arbejde »Socialismens udvikling fra utopi til videnskab ${ }^{1}$. Mit argument i det følgende er, at to velkendte »kendsgerninger « om Marx, Engels og deres synspunkter i virkeligheden er ren fiktion.

Den første fiktion hævder, at Marx og Engels taler som med en stemme i alle væsentlige teoretiske spørgsmål; at der, hvor de har helliget sig hver forskellige områder, supplerer deres arbejder hinanden; og at de delte deres arbejde i et perfekt intellektuelt partnerskab. Den anden fiktion hævder, at efterhånden som Marx blev ældre, nærmede han sig »positivismen, der dengang var så fashionabel i intellektuelle kredse «. Det stærkeste bevis herfor er påstanden om, at han bifaldt Engels' Anti-Dühring fra 1877-78 og i princippet var enig i andre af Engels' arbejder, såsom Naturdialektikken.

Skønt enhver præsentation af marxismen uundgåeligt knytter an til nogle af Marx' egne tekster, så er hans arbejder meget ofte blevet underkastet fortolkninger på måder, som var inspireret af Engels. Kommentatorer har således tilsluttet sig eller afvist en blanding af Marx og Engels uden overhovedet at overveje den mulighed, at deres individuelle synspunkter adskilte sig i spørgsmål af teoretisk vigtighed ${ }^{2}$. Selvom stadig flere ikke længere accepterer den første fiktion, så diskuteres de spørgsmål, som dette rejser, alligevel ikke ${ }^{3}$. Og der er tale om vigtige spørgsmål, fordi Engels'

* Terell Carver er ansat på University of Bristol og artiklen er oprindeligt publiceret i Political Studies, Vol. XXVIII, No. 3, p. 353-363.

1. David McLellan, Karl Marx: His Life and Thoughts, London 1973 p. 423. For en generel diskussion af nogle af de her rejste emner se Paul Thomas, »Marx and Science«, Political Studies, 24, 1976, p. 1-23. Se også Norman Levine, The Tragic Deception: Marx contra Engels, Oxford og Santa Barbara 1975.

2. For eksempel Karl Popper, R.N. Carew-Hunt, H.B. Acton, John Plamenatz, Bertram Wolfe, Alfred Meyer, Michael Evans og andre.

3. Se for eksempel George Lichtheim, Marxism, London 1967 pp. 234-43; Shlomo Avineri, The Social and Political Thought of Karl Marx, Cambridge 1969, p. 3; Alfred Schmidt, The Concept of Nature in Marx, London 1971, pp. 51-61; Bertel Ollman, Alienation: Marx' Concept of Man in Capitalist Society, Cambridge 1971, p. XV; David-Hillel Ruben, Marxism and Materialism, Hassocks, Sussex 1977, p. 5; og John McMartry, The Structure of Marx' World-View, Princeton, 1978 p. 7 og 158. I Karl Marx, London, 1975, minimerer Michael Evans alle forskelle mellem Marx og Engels, der eventuelt måtte vise sig at eksistere se pp. 20-21 og 78-79. 
arbejder har været langt mere virksomme somme end Marx' i prægningen af marxismen og debattraditionen om den.

Gennem en undersøgelse af det mest afgørende i standpunktet om overensstemmelsen mellem Marx og Engels, nemlig påstanden om, at Marx bifaldt Anti-Dühring, håber jeg at kunne rokke ved billedet af det perfekte partnerskab og at bidrage til en genvurdering af Marx' arbejder om de klassiske problemer for filosofien og samfundsvidenskaberne.

\section{Marx, Engels og Dühring}

I et brev den 7. januar 1868 gjorde Engels Marx opmærksom på en »yderst morsom« ting. Det var en anmeldelse af det nyligt udgivne første bind af Kapitalen af Eugen von Dühring fra Berlins universitet. Den følgende dag svarede Marx, at Dühring havde »åbenlyst misforstået forskellige ting», hvor den »løjerligste « var, at han havde forvekslet Marx med Lorenz von Stein, »fordi jeg udvikler dialektikken mens Stein tankeløst roder de mest trivielle ting sammen til klodsede triader med nogle få Hegelske kategoriskift». Marx helligede sig i nogen tid Dührings arbejder om filosofi og politisk økonomi, og underrettede muntert Engels om deres værdiløshed, men det bragte dog ikke noget svar for dagen andet end et løfte fra Engels om at returnere et eksemplar af Dührings arbejde om Carey's politiske $\emptyset \mathrm{konomi}^{4}$.

Fordi Dühring var kender af både Hegels filosofi og samtidens politiske $\emptyset$ konomi var han en speciel interessant modstander for Marx. Som teoretiker truede han Marx' ambitioner inden for den internationale socialisme; ambitioner der blev næret af hans passionerede tro på præcisionen i sit eget arbejde. I et brev til vennen Kugelmann d. 6. marts 1868 nævnte Marx begge aspekter af Dührings arbejde og fremhævede:

»Min bog har begravet ham i begge henseender ... Han ved meget vel, at min udviklingsmetode ikke er den hegelske, eftersom jeg (er) materialist og Hegel idealist. Hegels dialektik er grundformen for al dialektik, men først efter fjernelsen af dens mystiske form, og det er netop det, der kendetegner min metode. Med hensyn til Ricardo så har det i den grad givet hr. Dühring spat, at de svage punkter, som Carey og hundrede andre før ham har fremhævet hos Ricardo, ikke eksisterer i min fremstilling. Han forsøger derfor af ond vilje at laste mig for Ricardos bornertheder. Men uanset det, må jeg være manden taknemmelig, da han er den første fagmand, der overhovedet har ytret sig $\ll^{5}$.

4. Karl Marx og Friedrich Engels, Werke (MEW), Berlin 1956 ff., Bd. 32, pp. 8, 9, 11-12, 30, 46, 49, 722, n. 12.

5. MEW, Bd. 32, pp. 538-539. 
Marx sagde også, at Dühring - skønt han lod som om han forsvarede Wilhelm Roschers politiske $\varnothing$ konomi - i virkeligheden $»$ ikke var ked af, at Roscher, som spærrer vejen for alle (Dühring og andre yngre akademikere) får et los», og at dette delvis forklarer, hvorfor Dühring overhovedet beskæftiger sig med Kapitalen ${ }^{6}$. Marx synes at have betragtet Dühring som en alvorlig plage snarere end som en alvorlig intellektuel.

Dühring fortsatte med at udgive sin Kritische Geschichte der Nationalökonomie und des Sozialismus i 1871 og Cursus der Nationalund Socialökonomie i 1873. I 1875 udkom en 2. udgave af hans Kritische Geschichte ligesom hans Cursus der Philosophie als Streng Wissenschaftlicher Weltanschauung und Lebensgestaltung. Dührings værkers indflydelse blandt tyske socialister blev specielt beklaget af en af deres ledere, Wilhelm Liebknecht, som skrev til Engels den 1. februar, 21. april og 1. november 1875 og pressede ham for at angribe Dühring i den socialistiske avis Volksstaat. Engels synes dog ikke at have betragtet sagen helt så presserende.

En rosende artikel om Dühring kom Engels for øje den 16. maj 1876 og den 24. maj skrev han til Marx og udtrykte bekymring over, at Dühring havde fået en meget højrøstet tilhænger i den socialistiske lejr. Den vanskelighed dette skabte - et angreb på Dühring ville blive taget som et angreb på visse personer inden for partiet - var yderligere et problem. I »raseri« spurgte han Marx, »om det ikke snart var på tide, at overveje vores standpunkt vis-á-vis denne gentleman omhyggeligt?« Det fremgår, at drivkraften bag Anti-Dühring var Engels selv, og ikke Marx. Ikke overraskende svarede Marx samtykkende Engels: »Min mening er, at 'standpunktet vis-á-vis denne gentleman' kun kan fremlægges ved at kritisere Dühring uden barmhjertighed «?

Den 28. maj 1876 skrev Engels til Marx med nyt om sine planer for angrebet på Dühring og hans arbejder. Dührings Cursus der Philosophie afslører iflg. Engels bedre »de svage sider og grundlaget for argumentationen som introduceres $i$ » $\varnothing$ konomien««, der jo ellers må antages at være af størst interesse for socialister. Engels' plan er imidlertid logisk. Dührings »banaliteter», siger han, er afsløret »i en mere simpel form end i økonomibogen«, og Engels foreslår at behandle begge sammen.

6. Marx til Engels, 8. januar 1868, MEW, Bd. 32, p. 11.

7. Den højrøstede tilhænger var Johann Most, MEW Bd. 20, p. 623, n. 1; Bd. 34, pp. 1213, 14, 541-42 nn. 18, 21, 26. Se også Oscar Hammen, 'Alienation, Communism and Revolution in the Marx-Engels Briefwechsel', Journal of the History of Ideas, 33, 1972, p. 81-82, hvor det som et resultat af en meget selektiv citation sluttes, at drivkraften bag Anti-Dühring kom fra Marx. 
Således blev strukturen i Anti-Dühring stort set bestemt af de emner, som Dühring (iflg. Engels ganske overfladisk) behandlede. »Om rigtig filosofi«, klagede Engels, »formel logik, dialektik, metafysik osv. står der intet. Det skal snarere forestille at være en generel videnskabsteori«, hvor »naturen, historie, samfund, stat, lov osv. diskuteres i en angivelig videre sammenhæng $\ll^{8}$.

I løbet af sommeren rapporterer Engels fra Ramsgate om sine fremskridt, mens han latterliggør Dührings ideer om naturen, men uden at nævne sin egen »dialektiske « tilgang: »Svarende til den stadig mere fortættede landliggersløvhed var min læsning naturligvis hr. Dührings natur-filosofi om virkeligheden. Jeg har aldrig før mødt noget så naturligt som dette. Det drejer sig alt sammen om naturlige ting, eftersom alt hvad hr. Dühring synes er naturligt også regnes for naturligt, og han går således altid udfra »aksiomatiske grundsætninger «, for det som er naturligt behøver intet bevis « ${ }^{9}$.

Marx kommenterede øjensynligt ikke dette eller overhovedet Engels' projekt før d. 3. marts 1877, hvor han rapporterer om en andens (P.L. Lavrov's) reaktion på de første afsnit af Anti-Dühring, der blev trykt i avisen Vorwärts mellem d. 3. januar og d. 13. maj 1877.

Iflg. Marx roste Lavrov arbejdet, men sagde, at man ikke var vant til en sådan » mildhed « i Engels' polemiske skriverier ${ }^{10}$. Imidlertid havde Engels åbenbart bedt Marx om at undersøge Dührings arbejde om politisk $\phi k o n o-$ $m i$, og d. 5. marts sendte Marx sin »Dühringiana « i et brev til Engels, hvor han udtrykte en begejstret kritik, men ingen virkelig respekt for Dühring eller hans synspunkter:

»Det var mig umuligt at læse karlen uden bestandig at slå ham grundigt $\mathrm{i}$ hovedet. $\mathrm{Nu}$, efter at jeg har læst mig ind på ham (og delen fra Ricardo og frem, som jeg endnu ikke har læst, må indeholde mange kostlige perler), hvilket krævede tålmodighed, men samtidig at man havde kneblen i hånden, er jeg for fremtiden i stand til at nyde ham $\mathrm{i}$ ro. Har man engang arbejdet sig ind på fyren, så man har krammet på hans metode, så er han på en vis måde en opmuntrende lille skriver « ${ }^{11}$. Engels svarede, at Marx' »kritiske historie « var »mere end jeg behøver for at blanke karlen fuldstændig af på det felt«, og at hans ven Lavrov »ikke vil have flere indvendinger om mildhed efter sidste ord om »Filosofien « og endnu mindre »Økonomien«. Engels arbejdede på den økonomiske del af Anti-Dühring fra juni til august 1877. Han fremhævede (i et privat brev)

8. $\quad$ MEW, Bd. 34, p. 17.

9. ibid, p. 27.

10. ibid, p. 34 .

11. ibid, p. 36 . 
Marx' hjælp og den 8. august sendte Marx ham nogle noter om Quesnay's Tableau Economique, et af de arbejder Dühring havde gennemgå ${ }^{12}$. Derefter ophører kommentarerne om indholdet i Anti-Dühring i Marx-Engels korrespondancen. Det materiale, som Marx udarbejdede til Engels blev ikke udgivet fuldt ud i den første udgave af Anti-Dühring som en komplet bog (Leipzig, 1878). Først i forordet til anden udgaven (Hattingen-Zürich, 1886) anerkendte Engels Marx' forfatterskab, og først i tredie udgaven (Stuttgart, 1894) forklarede Engels nøje, hvorfor han havde skåret ned på det materiale, som Marx havde sendt ham. I sit forord til anden udgaven skrev Engels, at Marx' kapitel »måtte jeg forkorte noget af helt ydre årsager «, men i 1894-forordet uddybede han dette, idet han skrev, at i visse dele af manuskriptet »var kritikken af Dührings fremstilling overskygget af Marx' egne udviklinger med hensyn til økonomiens historie«. Engels forklarede så, at »hvor gangen i argumentationen gør det muligt«, har han nu »udeladt passager der refererer udelukkende til hr. Dührings skriverier «, og trykt Marx' arbejde om Pette, North, Locke, Hume og Quesnay i stedet for! « ${ }^{13}$

Det er først i forordet til anden udgaven, dateret d. 23. september 1885 (efter Marx’ død i 1883), at Engels hævder, at han »læste hele manuskriptet « for Marx »før det blev trykt «. Der er intet i Marx-Engels' korrespondance, i deres arbejder eller nogen andre steder, der underst $\varnothing t t e r$ dette.

I 1885-forordet til Anti-Dühring skriver Engels også, at hans »fremstilling « af Marx-Engels' »verdensanskuelse « ikke skulle udkomme uden Marx' »vidende«. Dette, skriver Engels, var »underforstået « mellem dem. Han gir således læseren indtryk af, at Marx bifaldt hans arbejde, som et udtryk for »deres « anskuelse, mens han undgik påstanden, at Marx samtykkede i noget sådant. Der er ingen kendte svar eller korrektioner fra Marx om indholdet $\mathrm{i}$ Engels' arbejde. I virkeligheden synes Engels ikke at have afsløret offentligt, mens Marx levede, at Marx havde hjulpet ham med bogen, og der synes ikke at have været noget fors $\varnothing \mathrm{g}$ på at sætte Marx' navn på bogen.

I 1885-forordet hævdede Engels imidlertid meget mere end at Marx blot bifaldt manuskriptet. Engels argumenterer for, at han var nødt til at imødegå Dührings system med et positivt alternativ, ikke blot en negativ kritik. Hans polemik, siger han, »slog om i en mere eller mindre sammenhængende fremstilling på en temmelig omfattende række områder af den dialektiske metode og kommunistiske verdensanskuelse, som Marx og jeg var forkæmpere for. Denne anskuelsesmåde måde (sic), der er

12. ibid. pp. 37, 63, 68-70. En offentliggjort version af Marx' manuskript er udkommet som Karl Marx, »Randnoten zu Dührings Kritische Geschichte der Nationalökonomie «, i: Friedrich Engels, Herrn Eugen Dührings Umwälzung der Wissenschaft (und) Dialektik der Natur 1873-1882, Sonderausgabe, ed. V. Adoratskij, Moskva 1935, pp. 340-71. Jeg er taknemlig for lånet af dette bind fra Lenin-biblioteket i Moskva.

13. Friedrich Engels, Anti-Dühring, MEW, Bd. 20, pp. 8ff; ibid pp. 623-26, n. 1. 
vores, ... finder nu anerkendelse og støtte langt ud over Europas grænser, i alle lande, hvor der på den ene side findes proletarer og på den anden side uforfærdede videnskabelige teoretikere«. Denne offentlighed er iflg. Engels interesserede nok til at tage "polemikken mod Dührings læresætninger med i købet blot for at få den positive fremstilling «. Engels tilskriver Marx den største andel i udviklingen af »anskuelsesmåden fremstillet i denne bog «, og så tilføjer han, at det »var underforstået (sic) mellem os, at min fremstilling ikke skulle udsendes uden hans vidende « ${ }^{14}$.

Men i hans overleverede korrespondance med Marx gjorde Engels ikke noget stort krav på at have modgået Dührings system med »dialektisk metode $\ll$ og »kommunistisk verdensanskuelse «. Redegørelsen skrevet $f \phi r$ Marx' død viste meget mere begrænsede mål:

»Min plan er klar. Først og fremmest skal jeg behandle dette møg på en rent objektiv og tilsyneladende alvorlig måde, og så vil behandlingen blive mere og mere skarp efterhånden som beviserne på sludret på den ene side og platituderne på den anden side hober sig op, indtil et rent uvejr til sidst bryder løs over ham $\ll^{15}$.

I 1885-forordet til Anti-Dühring kommer Engels imidlertid på gled med sit forehavende. I en frisk jargon annoncerer han den første forudsætning for det vi nu betragter som den dialektiske materialisme: »Marx og jeg var stort set de eneste folk, der reddede den bevidste dialektik fra den tyske idealistiske filosofi og anvendte den på den materialistiske opfattelse af naturen og historien $\ll^{16}$.

Engels argumenterer for, at »bevidst dialektik « udtrykkes i love om »den totale simpelhed og almengyldighed « som kun opdages i naturen, historien og »tænkningen « ved at »arbejde med begreber «, dvs. rekapitulere og genskrive naturvidenskaberne, historien og matematikken ${ }^{17}$. Om opdagelsen af de dialektiske love i historien og »tænkningen « siger Engels ikke mere i 1885-forordet, fordi han foretrækker at koncentrere sig om opdagelsen af de dialektiske love i naturen ${ }^{18}$.

\section{Naturdialektik}

Engels' »resultater« - bortset fra dem, som fremkom i Anti-Dühring fandtes i det manuskript, som blev offentliggjort efter hans død som $\mathrm{Na}$ -

14. Engels, Anti-Dühring, pp. 8f.

15. Engels til Marx, 28. maj 1876, MEW, Bd. 34 p. 17.

16. Engels, Anti-Dühring, p. 10.

17. David McLellan kommenterer forskellen mellem Engels' fokuseren på naturen og Marx' koncentration om historien; se Engels, Glasgow 1977, p. 73.

18. Deres opdagelser inden for matematikken lægger han tilside som et projekt for en »senere lejlighed, hvor de resultater jeg er nået til kan sammenstilles og publiceres, måske i sammenhæng med de ekstremt vigtige matematiske manuskripter Marx efterlod «. Engels, Anti-Dühring, pp. 10-12. 
turens dialektik. Faktisk afbrød han arbejdet med dette manuskript for at skrive Anti-Dühring. Den umiddelbare tilskyndelse for Engels til at beskæftige sig med en dialektisk tolkning af naturvidenskaberne havde været hans meget kritiske reaktion på anden udgaven af Ludwig Büchners Man and his Place in Nature in the Past, Present and Future. Or: Where did we come from? Who are we? Where are we going? Planen om en kritik stammer fra meget tidligt i 1873, og i et brev til Marx fra 30. maj formulerer han sine »dialektiske ideer om naturvidenskaberne « og beder om hjælp: »Mens jeg lå i min seng i morges fik jeg følgende dialektiske ideer om naturvidenskaberne: Naturvidenskabernes genstand - stof i bevægelse, legemer. Legemer kan ikke adskilles fra bevægelse, deres form og art kan kun erkendes gennem bevægelse; man kan intet hævde om legemer som er ude af bevægelse, ude af relationer til andre legemer. Kun i sin bevægelse afslører legemet, hvad det er. Naturvidenskaberne erkender derfor legmer ved at iagttage dem i deres relation til hinanden, i bevægelse. Viden om de forskellige former for bevægelse er viden om legemer. Unders $\emptyset$ gelsen af bevægelsens forskellige former er derfor naturvidenskabernes centrale emne... Eftersom du er placeret i naturvidenskabernes højborg, er du bedst istand til at vurdere om der er noget i sagen $\ll^{19}$.

Marx' svar til dette var venligt, kort og uforpligtende: Har lige modtaget dit brev, som glædede mig meget. Men jeg vil ikke forivre mig med en opfattelse af sagen, før jeg har haft tid til at tænke den igennem og konsultere »autoriteterne $\ll^{20}$. »Autoriteterne « synes - så vidt vi ved - ikke at have været særlig imponeret over Engels' indsigter, omend Marx fors $\varnothing$ gte at fortælle ham det pænt. Carl Schorlemmer, for eksempel, bemærker i randnoter på Engels' brev, at han er enig i, at »undersøgelsen af disse forskellige former for bevægelse er naturvidenskabernes centrale emne«, og at et enkelt legemes bevægelse må behandles relativt (»Helt rigtigt«). Men når Engels skriver, at dialektik, som den videnskabelige verdensanskuelse, ikke selv kan bevæge sig frem fra kemi til »organisk videnskab « før kemien selv gør det, og derefter skriver (i relation til biologi) »Organisme - her vil jeg ikke for tiden gå ind i en dialektisk udredning «, så kommenterer Schorlemmer det »Ej heller vil jeg « ${ }^{21}$. Marx’ »autoritet « på området fandt det naturvidenskabelige indhold i Engels' brev mere acceptabelt end det dialektiske.

Der findes ikke mere overleveret korrespondence mellem Marx og Engels omkring Naturens dialektik før Engels' brev af 21. september 1874, hvori han bemærker, at artikler af Tyndall og Huxley i Nature har »ka-

19. MEW. Bd. 20 pp. $646-50$, note 162 , og p. 666 , note 276 . MEW. Bd. 33 p. 80 f.

20. MEW. bd. 33 p. 82.

21. MEW. bd. 33 pp. $80-81,82,84$. 
stet mig ... tilbage til dialektik-temaet igen. ${ }^{22}$ Heller ikke denne gang er der nogle overleverede kommentarer fra Marx, skønt han adskillige gange refererede til Engels' projekt og endog foretog korte forespørgsler for ham. Den 7. oktober 1876 skrev han til Wilhelm Liebknecht: »Kære bibliotek ... Engels har travlt med Dühring-arbejdet. Det er et stort offer fra hans side, fordi han måtte afbryde et uforholdsmæssigt meget vigtigere arbejde for at lave det. $\ll^{23}$

Og til Wilhelm Alexander Freund skriver han den 21. januar 1877: »Kære ven Freund... Skulle De træffe Dr. Traube ... så vær så venlig at minde ham $\mathrm{om}$, at han har lovet at sende mig titlerne på sine forskellige publikationer. Det er meget vigtigt for min ven Engels, som arbejder med et værk om naturfilosofi, hvor han - viser det sig - vil understrege Traubes resultater. ${ }^{24}$ Til Wilhelm Blos skriver han den 10. novenber 1877: »I øvrigt tvinger mit helbred mig til at anvende den af lægen tilladte arbejdstid til at færdiggøre mit værk; og Engels som arbejder på forskellige større arbejder (Naturens dialektik), forsyner stadig Vorwärtz med bidrag (Anti-Dühring et al.) « ${ }^{25}$ Der er ingen antydning her af, at Marx identificerede sig med nogen af Engels' arbejder eller anså dem for at være et aspekt af deres »anskuelse«. I en senere meningsudveksling om Engels' forskning i forbindelse med Naturens dialektik var Marx endog meget kortfattet. Den 23. november 1882 skrev Engels: »Elektriciteten har beredt mig en lille triumf. Måske kan du huske min diskussion af Descartes-Leibnizstriden ... Modstand udgør i elektriciteten det samme som masse gør i mekanisk bevægelse. Det viser sig altså, at i den elektriske, som i den mekaniske bevægelse - det ene sted hastighed, det andet sted strømstyrke - virker den kvantitativt målelige fremtrædelsesform for denne bevægelse i tilfælde af simpel overføring uden formforandring som en simpel faktor i første potens; i tilfælde af overføring med formforandring som en kvadratisk faktor. Dette er en generel naturlov for bevægelse, som jeg har formuleret for første gang. $\ll^{26}$

Her er Marx svar af 27. november: »Bekræftelsen på kvadratets rolle $i$ overførsel af energi under dennes formforandring er meget smuk og jeg gratulerer dig. $\ll^{27}$

Der blev ikke udvekslet noget, der var blot det mindste væsentligt omkring Engels' projekt mellem de to efter dette. Marx døde i marts 1883 og Engels opgav arbejdet med manuskriptet i 1886.

22. MEW. bd. 33 pp. 119-20.

23. MEW. bd. 34. p. 209.

24. MEW. bd. 34. pp. 245-46.

25. MEW. bd. 34 p. 311.

26. MEW. bd. 35 pp. 118-19.

27. MEW. bd. 35 p. 120. 


\section{Det perfekte partnerskab?}

Den overleverede Marx-Engels korrespondence kan ikke understøtte det billede, Engels har malet i 1885-forordet til Anti-Dühring. Marx diskuterede ikke Engels' dialektiske love, ikke engang når han blev opfordret til det; ej heller sagde han noget, som kunne understøtte den påstand, at han og Engels var fælles talsmænd for en universel materialisme. Marx sagde intet, som kan bekræfte Engels påberåben sig, at Marx var fortrolig med hele teksten i Anti-Dühring, og endnu mindre at han bifaldt den i sin helhed.

Desuden bekræfter Marx-Engels-korrespondancen ikke det traditionelle billede af deres »tætte samarbejde « om alle emner, først og fremmest deres teoretiske arbejde. I virkeligheden antyder korrespondancen kraftigt, at de to bortset fra politiske nyheder, familiesladder og partisager arbejdede uafhængigt af hinanden for det meste, og at anmodninger om råd omkring fundamentale teoretiske problemer fra den ene eller den anden side gav meget lidt substantielt indhold.$^{28}$ Hvis meget betydningsfulde meningsudvekslinger fandt sted, når de to faktisk mødtes, ville breve af den slags som er overleveret ganske sikkert have afspejlet dette, eller i det mindste ville de ikke være så overfladiske og uforpligtende. Den hypotese, at de to mænd havde vigtige teoretiske diskussioner privat passer ikke sammen med de kommentarer, de faktisk lavede i deres breve. Hvis der havde været materiale, som støttede de dialektiske og materialistiske standpunkter, som blev fremsat af Marx' litterære eksekutor (Engels), eller hvis der havde været beviser for, at deres intellektuelle forhold virkelig var så monolitisk, som Engels senere hævdede, hvem i Marx' familie eller blandt deres socialistiske kolleger ville så have haft en interesse i at tilintetgøre det? Kommentatorer, som accepterer eller fremsætter det traditionelle standpunkt, at alle Marx' og Engels' arbejder er konsistente og supplerer hinanden igennem hele deres karriere, burde give positive beviser, som refererer begge sider af korrespondancen, og viser ud over Engels' ubekræftede beretninger - især de, som er skrevet efter Marx' død.

Men, hvis Marx faktisk var alvorligt uenig med Engels om substansen i Anti-Dühring, hvorfor tog han så ikke afstand fra den? Eller havde han overhovedet aldrig læst den (eller lyttet til den)?

28. Den formodning, at Marx skulle $\emptyset$ nske Engels som medforfatter til Kapitalen, er noget vrøvl. I et brev af 7.7. 1866 spørger Marx Engels om han kunne tænke sig at skrive et »appendix « om krigsindustrien og således fremstå som »direkte medarbejder « $\mathrm{i}$ »mit hovedværk «. Engels sagde, at han ville prøve, men leverede faktisk aldrig noget. MEW. bd. 31 p. 234. Den fejlagtige formodning er fremsat af Thomas Sowell: »Marx' Capital after One Hundred Years « in: M.C. Howard og J.E. King (eds.) »The economics of Marx, Harmondsworth, 1976, pp. 74-75, note 51. 
Anti-Dühring udkom i løbet af 1877-78 som hæfter i Vorwärts, som Marx let kunne have læst, og den blev også udgivet som tre pamfletter (1877-78) og som bog (1878). Selv hvis Engels' historie om, at han havde læst manuskriptet op for Marx var usand, eller hvis Marx ikke lyttede efter, så synes det totalt meningsløst at forestille sig, at han var helt ubekendt med indholdet.

Min påstand er, at Marx følte det var lettere - set i forhold til deres lange venskab, deres rolle som ledende socialister og nytten af Engels' økonomiske formåen, - at tie stille og blande sig udenom Engels' arbejde. Når alt kom til alt, udkom Anti-Dühring under Engels' navn alene, og hverken Engels eller Marx synes, mens Marx levede, at have afsløret for offentligheden, at Marx havde bidraget til kapitlet om politisk økonomi.

Det er interessant, at Engels ikke hævder, at have vist Marx Naturens dialektik, som han arbejdede på fra 1873 til 1886. I dette arbejde blev hans synspunkter på »dialektikkens almene natur « formuleret eksplicit, hvilket ikke var tilfældet i den første udgave af Anti-Dühring. Rendyrkningen af Engels' dialektik, som den findes i forordet til Anti-Dühring fra 1885 sætter hele bogen i et andet lys. Det synes som om Engels var klog nok til at undgå at skabe uoverensstemmelser med Marx. Og som om Marx ligeledes var klog nok til ikke at udfritte Engels om hans arbejde.

Det var muligt for Marx at tage det standpunkt, at den første udgave af Anti-Dühring ville gøre mere gavn end skade, fordi han afskyede Dührings standpunkter, og fordi Engels slår ned på dem uden barmhjertighed. Marx anbefalede også bogen til andre og refererede næsten slagordsagtig til Engels' »positive resultater « og til Anti-Dührings politiske værdi i forhold til en »korrekt vurdering af den tyske socialisme«. Men han forpligtede sig ikke overfor alle dele af teksten, eller til at den skulle kunne læses i stedet for Kapitalen, en opfattelse som Engels opmuntrede i private sammenhænge - især efter at han havde offentliggjort nogle få kapitler af den på fransk som pamfletten Socialismens udvikling fra utopi til videnskab i $1880 .{ }^{29}$ Sidst af alt stod Marx inde for Engels' senere kommentarer til Anti-Dühring og for det, han senere hævdede om forholdet mellem deres forskellige arbejder.

29. Friedrich Engels: Dialectics of Nature, Moskva 1954, pp. $270-73$ (skrevet i 1873) pp. 29-54 (skrevet i 1875 eller 1876), pp. 83-91 (skrevet i 1879); Marx til Wilhelm Bracke, 11.4. 1877 in MEW. bd. 34 p. 263-64; Marx til Moritz Kaufmann, 3.10. 1878 ibid. p. 346; Engels til F.A. Sorge, 9.-16. november 1882 in MEW bd. 35 p. 396. Marx' noget distancerede forord til Socialismens udvikling fra utopi til videnskab blev (uvist af hvilke årsager) publiceret som Paul Lafargues arbejde MEW. bd. 19 pp. 181-82, 564. 


\section{Arbejdsdeling?}

I forordet til Anti-Dühring fra 1885 lagde Engels op til, at hans læsere skulle konkludere, at i forholdet mellem Marx og Engels blev naturvidenskaberne overladt til den sidste: ».. kendskab til matematik og naturvidenskab er væsentlig for en dialektisk og samtidig materialistisk opfattelse af naturen. Marx var en grundig matematiker... $\ll^{30}$ Overlod Marx i virkeligheden naturvidenskaberne til Engels? Eller $\emptyset$ nskede han blot ikke at arbejde med naturvidenskaberne på samme måde som han var startet at arbejde med den politiske $\varnothing$ konomi og planlagde at gøre med »jura, moral, politik etc.? «11

Det fremgår klart af Marx' arbejder, at han var alvorligt interesseret i naturvidenskaberne omend interessen var underordnet (som alt andet) hans kritik af den politiske $\varnothing$ konomi. Der er ingen støtte for en formodning om, at naturvidenskaben blev overladt til Engels, eller at denne videnskab i Marx' $\varnothing j n e$ krævede en 'kritik' af den slags, som hans ven tilbød for at skære den til så den passede med hans egen opfattelse af historie og samfund. Desuden gav Marx aldrig sin tilslutning til eller hævdede noget omkring natur, historie og »tænkning « i sine overleverede breve eller arbejder, som blot fjernt ligner Engels' entusiastiske spekulationer over dialektikkens evne til at begribe »tingene og deres repræsentation, i deres væsentlige forbindelse, sammenkædning, bevægelse, oprindelse og mål.«32

En af Marx' bedst kendte kommentarer om naturvidenskaberne fremkommer i Kapitalen, hvor han skriver at kemiens molekyleteori illustrerer Hegels analyse af transformationen fra kvantitet til kvalitet. Marx citerer her Hegel og molekylærteorien for at støtte sin påstand om, at det kvalitative skift fra håndværker til kapitalist følger af en akkumulation af varer eller penge ud over et kritisk mængde. ${ }^{33}$ Hvad Marx aldrig hævdede er, at der er dialektiske love for stof i bevægelse, som sætter sig igennem i disse transformationer, »den store grundlæggende proces « som Engels kaldte det i 1885-forordet til Anti-Dühring. ${ }^{34}$ Når Marx i Kapitalen refererede til en overensstemmelse mellem Hegels' angiveligt »rent « begrebslige analyse og givne forklaringer på visse fysiske og sociale fænomener, så påpegede han blot at Hegels indsigt passer i bestemte situationer. Når Marx benævnte Hegels konklusion en »lov«, mente han hermed, at under nogle omstændigheder kan vi forvente, at kvantitativ akkumulation

30. Engels Anti-Dühring p. 10.

31. Karl Marx, Economic and Philosophical Manuscripts, Harmondsworth, 1975 p. 281.

32. Engels, Anti-Dühring p. XXX.

33. Marx, Das Kapital, MEW. 23, p. 327.

34. Engels, Anti-Dühring p. 13. 
vil skabe kvalitative forandringer. I og med denne bemærkning i Kapitalen havde Marx hverken skrevet under på Hegels metafysik eller Engels’ »videnskabelige « verdensanskuelse. På det tidspunkt, hvor Marx skrev om overensstemmelsen mellem hegelsk logik og teorien om kemiske forandringer, var den $n u$ klart kontroversielle karakter af hans ord ikke tydelig, fordi Engels' standpunkt, at et sæt af dialektiske love styrede alle fænomener, ikke blev offentliggjort eksplicit før efter Marx’ død. Marx beundrede berømte fysikeres og kemikeres metoder, men trak omhyggeligt grænser for analogier mellem hans egen og naturvidenskabsmændenes metoder. ${ }^{35}$

Skønt Marx hævdede eksistensen af materiel virkelighed som en forudsætning for sin teori, fremsatte han aldrig sine resultater som på nogen måde afledt af eller baseret på love for stof i bevægelse. Engels' »udvikling « fra »bevidst livsaktivitet « til molekylær bevægelse blev - så vidt vi ved - aldrig støttet af Marx. Selvfølgelig har bevidsthed noget at gøre med molekylær bevægelse, men der er ingen grund til at formode, at Marx (hvis han overhovedet kendte hele indholdet af Engels' tese) var mere overbevist end videnskabsmænd i dag er det, af Engels' »bevis « for at dialektiske bevægelseslove må ligge til grund for enhver tilfredsstillende teori indenfor psykologi, historie og andre natur- og samfundsvidenskaber. Engels kan have ret, men han har ikke påvist, at han har det.

Det, Marx har sagt om matematik, fysik, kemi, biologi ${ }^{36}$, antropologi eller logik, forstyrrer ikke dette billede. Han fulgte med i naturvidenska-

35. Marx, Das Kapital, MEW 23 p. 12.

36. Marx' kommentarer omkring Darwin er faktisk mere positive end det er blevet fremstillet af Sholomo Avineri. At Darwins overlevelseskamp i naturen, i følge Marx, lignede naturvidenskabsmandens eget samfund, var en vittighed om Darwin, men Marx siger ikke, at Darwins beskrivelse af planternes og dyrenes verden er forkert. Både Darwin (i første udgaven af Origin of Species) og Marx var uvillige til at gå fra konklusioner om planter og dyr til konklusioner om det menneskelige samfund.

Marx havde rent faktisk meget tilovers for Darwins arbejde, omend meget lidt for darwinisters. Darwins metode lignede hans egen på et afgørende punkt. Darwin postulerer eksistensen af, hvad vi nu ved er genetiske mekanismer, som ligger bag ved tilsyneladende usammenhængende (eller kun mystisk sammenhængende) fænomener, som han observerer. På samme måde hævder Marx at »bestemmelsen af værdiens størrelse ved hjælp af arbejdstiden er en hemmelighed, skjult under bevægelserne i varernes relative værdier «. Dette var også en af grundene til, at Marx var interesseret i den højere matematik: Bag ved komplekse matematiske udtryk gemmer sig undertiden skjulte løsninger, ofte enkle formler. Se Sholomo Avieneri: From Hoax to Dogma: A Footnote on Marx and Darwin. In Encounter (1967) p. 30. For en opsummering omkring Marx-Darwin-affæren se Terrence Ball: Marx and Darwin: A Reconsideration, in Political Theory, 7 (1979) p. 469-82 (Jeg er forfatteren taknemlig for tilladelsen til at se dette manuskript før offentliggørelsen). For en diskussion af Marx’ matematiske manuskripter se D.J. Struik: Marx and Mathematics « in Science and Society, 12 (1948) p. 181-96. Marx' brev til Engels 18.6. 1862 in Selected Correspondance p. 128. Marx Das Kapital MEW 23 p. XXX. Marx' brev til Engels 8.1. 1868 MEW bd. 32 pp. 11-12. 
berne, matematikken, historien og filosofien med stor energi (i stærk modsætning til den fiktive tese om arbejdsdeling) og dette førte aldrig til en støtte til den materialistiske dialektik, som Engels dyrkede.

\section{Konklusion}

Hverken Marx-Engels-korrespondancen eller bemærkningerne om socialeller naturvidenskaberne i Marx' arbejder støtter den »videnskabelige « verdensanskuelse, som blev fremstillet af Engels efter Marx' død og udviklet i Engels' posthumt udgivne skrifter. Der er ingen love for dialektikken i Marx' forord til Bidrag til kritikken af den politiske фkonomi fra 1859, i hans populære arbejde $L \phi n$, pris og profit, i hans hovedværk $K a$ pitalen, og dermed forbundne manuskripter, eller i hans sidste arbejde af teoretisk interesse Randnoter til Adolph Wagner.

Det, Marx faktisk siger om social- og naturvidenskaberne i disse arbejder, passer ikke med Engels' grandiose påstande om stof $i$ bevægelse og dialektiske love. Og den usikkerhed, de huller og den stilfulde undvigen, som udspiller sig i Marx' svar til Engels, viser ikke det perfekte partnerskab om dette store teoretiske emne og heller ikke om nogen andre vigtige teoretiske emner, så vidt jeg kan se.

Det faktiske forhold mellem Marx' standpunkter (som de kommer til udtryk i de ovennævnte arbejder) og Engels' generelle love udgør et interessant debatfelt for enhver, som beskæftiger sig med samfundsvidenskabernes karakter. Men der kan ikke skabes nogen debat, hvis man går uden om spørgsmålet om forskellen mellem Marx' og Engels' standpunkter eller, hvis denne forskels karakter forbliver uunders $\emptyset \mathrm{gt}$. 


\section{Frauenoffensive \\ ein Verlag der Frauenbewegung}

Verlag Frauenoffensive udgiver bl.a. vigtige bidrag til en teoretisk diskussion af kønsforholdet, kønsarbejdsdelingen, kvindearbejdet og kvindeundertrykkelsen.

Af forlagets udgivelser kan nævnes:

\section{Anke Wolf-Graaf »Frauenarbeit im Abseits« $123 \mathrm{Kr}$}

- en omfattende analyse af vigtige teoretiske strømninger i kvindebevægelsen samt et bidrag til analysen af kvindearbejdets historie.

Gertraude Kittler »Hausarbeit - zur Geschichte einer

'Natur-Ressource'« $69 \mathrm{Kr}$

Barbara Ehrenreich/Deidre English:

»Hexen, Hebammen und Krankenschwestern« $28 \mathrm{Kr}$

»Zur Krankheit gezwungen« $32 \mathrm{Kr}$

- disse to bøger fremstiller tilsammen kvindeundertrykkelsen siden middelalderen ud fra udviklingen i sygdomsbegrebet og det medicinske system.

Af andre udgivelser kan nævnes:

Eva-Maria Stark »Geboren werden und gebären

eine Streitschrift für die Neugestaltung von Schwangerschaft, Geburt und Mutterschaft« $\mathbf{5 4} \mathbf{~ K r}$

Anja Meulengelt »Feminismusaufsätze zur Frauenbefriung« $95 \mathrm{Kr}$

Ved køb direkte hos Kurasje ydes $20 \%$ rabat på Frauenoffensives udgivelser.

Kurasje, Krystalgade 14/16, 1172 K. giro 7166044 